\title{
「ナビゲーション医療分野」医療機器ガイドラインに関する 学会合同検討ワークショップ
}

\section{開催趣旨}

平成 17 年度より, 厚生労働省と経済産業省の共同事業として,「医療機器ガイドライン策定事業」 が開始されております。この事業は, 革新的な医療機器の開発から有効性安全性評価までのプロセス において必須の開発検討項目や評価の目安（ガイドライン）を，関係する医学・工学系学会の主導の もとに定めて, 研究開発者, 行政, 医療関係者で共有することでスムーズな事業化をサポートするこ とを主目的としております。そのテーマの一つとして，手術ナビゲーション，手術ロボットなどを包 含する「ナビゲーション医療」分野のガイドラインの策定が，関係学会を中心に進められております。

本学会では, ガイドライン策定の一環と致しまして, 学会としてのガイドラインの編纂を進めてお ります，本ワークショップは，その主要論点を中心に幅広く意見交換を行い，行政側の作業との整合 をはかるとともに，関連する分野で広範に支持されるガイドラインとする事を目的とするものです．

忌憚ないご議論とご指導を賜りますよう，お願い申し上げます。 


\section{プログラム (敬称略)}

1. 開会挨拶

慶應義塾大学・日本コンピュータ外科学会理事長 北島 政樹

2. 医療機器ガイドライン事業について

名古屋大学 吉田 純

3. ナビゲーション医療分野における技術的挑戦（海外動向も交えて）

東京大学 佐久間一郎

4. 各臨床科におけるナビゲーション医療の現状と, 関連する医療機器の課題

（ア）整形外科におけるナビゲーション医療の現状

大阪大学 菅野 伸彦

（イ）耳鼻咽喉科におけるナビゲーション医療の現状

金沢医科大学 友田 幸一

（ウ）脳神経外科におけるナビゲーション医療の現状

東京女子医大学 村垣 善浩

（エ）内視鏡外科におけるナビゲーション医療の現状

大阪医科大学 奥田 準二

（才）胎児外科におけるナビゲーション医療の現状

成育医療センター 千葉 敏雄

5. ナビゲーション医療分野の研究開発と普及にむけての法制度上の課題

慶應義塾大学 古川 俊治

6. ナビゲーション医療分野 ガイドライン学会案のポイントについて

九州大学 橋爪 誠

7. 総合討論

司会：東京女子医科大学 伊関 洋, 東京大学 佐久間一郎 指定発言：防衛医科大学 菊地眞

8. 閉会の辞

東京大学 土肥 健純 


\section{日本コンピュータ外科学会の \\ 「精密手術用機器技術ガイドライン」作業経緯}

精密手術用機器技術ガイドライン WG 座長

橋爪誠

当学会は 1992 年の発足以来, 世界に先駆けて コンピュータ外科 (Computer Aided Surgery) の 用語とコンセプトを提唱し，手術ナビゲーショ ン，手術ロボティクスなどの研究開発の展開を 主導してきました，会員総数は 800 人強（平成 18 年 9 月現在）と小規模ながら，本邦でこの分 野の研究開発と臨床応用に携わる指導的な医学 者と工学者, 意欲ある企業のほぼ全員が参加す る, 分野横断的な学会となっております.

コンピュータ外科分野では，わが国は研究で 世界をリードする反面，その臨床実績と製品化 の面で諸外国に比べて遅れていました．行政に あっては治験促進, 国内医療機器産業の劣勢と 医療費高騰などの問題意識から，厚生労働省が 平成 15 年 3 月に医療機器産業ビジョンを発表し て経済産業省と局長レベルの合意の下に国内の 医療機器産業と研究開発の促進策が進められる ことになりました。その一環として革新的な医 療機器の審査ポイントや収益予測の拠り所（評 価指標）など，事業化にあたって予測が困難な 点に関する評価指標を学界主導で定めて, 研究 開発者，行政，医療関係者で共有することでス ムーズな事業化をサポートする目的で，医療機 器ガイドラインが策定されることとなりました.

平成 15 年度から NEDO で医療機器ガイドライ ンの調查研究が開始され，コンピュータ外科分 野もその題材のひとつとされました。平成 15 年 6 月に当学会内にガイドラインワーキンググルー プが発足しました。当初は医学者, 工学者合わ
せて 9 名ほどの小さなグループとしてネットミ 一ティングによる活動を開始し，平成 16 年 4 月 に合宿形式の集中ミーティングを開催した際に, ほぼ現在の規模のメンバー（関係者約 30 名）に なりました。以後年に 1 回のペースで集中的な ディスカッションを行い，そのほかにネットミ ーティングなどで作業しています.

平成 17 年度から厚生労働, 経済産業両省によ る医療機器ガイドライン事業が開始され，同年 12 月から「ナビゲーション医療」という名でこ の分野のガイドライン策定する作業が開始され ました。本学会では今後, 積極的に行政の取り 組みとの整合を図ってまいります.

この分野ではISO/IEC, FDA など海外でも規 格化やガイダンス化が始まっていません，当学 会は Computer Aided Surgery のコンセプトを世界 に提案した学会として，また研究開発，製品実 現（薬事法承認申請），臨床運用のフェーズを横 断的にカバーできる, 指導的な医学者・工学者・ 企業が一堂に会する学会として, 関連学界の意 見を集約したガイドラインの提言を目指して作 業を進めてまいる所存です。本ワークショップ では作業案をオープンに議論することで，より 広範に支持され，役に立つガイドラインの提言 を目指す最初の試みと位置づけております。

今後も忌憚ないご議論とご指導を賜りますよ う，お願い申し上げます。 


\title{
ナビゲーション医療分野における技術的挑戦（海外動向も交えて）
}

\author{
東京大学大学院工学系研究科
}

佐久間 一 郎

外科領域では, 開腹などの大きな開創を必要 としない低侵襲外科手術 (minimally invasive surgery：MIS）が発達しつつある。低侵襲外科の 発展のためには狭い術野での正確な手術操作を 支援する技術の開発が求められる。ナビゲーシ ヨン医療分野の技術開発は，究極的には健常部 位には影響をもたらさず，疾患部位のみをピン ポイントで治療する「低侵襲標的精密治療技術」 へつながるものである。

このようなシステムの実現に必要となる技術 として

（1）患部の 3 次元位置情報に対応付けられた 病変の解剖学的形状情報，代謝や組織の 悪性度を示す機能情報を正確に低侵襲で 計測する技術

（2）生体計測情報 - 多次元医用画像計測情報 に基づき適切な治療計画の立案を支援す る技術

（3）患部を低侵襲に治療する技術

（4）低侵襲治療手段を正確に患部に運搬する 技術

（5）時々刻々変化する患者情報を計測・統合 し，的確な医師の判断を支援するととも に，治療システム全体の制御に統合化さ れた情報を利用する技術

が挙げられる,

（1）に関しては「分子イメージング」に代表 される，生きたままの組織・細胞の機能を in vivo で組織細胞の 3 次元位置・構造情報と関連 付けて計測する技術開発や各種の分子マーカー の開発が重要である。（2）はこのような多次元
の情報を統合して生体モデルを構築し，各種治 療シミュレーションを可能とする技術である。

（3）に関しては，近年の低侵襲手術の進歩に大 きく貢献した電気的治療機器，超音波凝固切開 装置, レーザ手術機器・超音波手術機器等の物 理的エネルギーによる新しい機器の高機能化や, 現在進められている超音波や電場を利用した局 所への遺伝子導入や薬物局所投与技術が挙げら れる。（4）はこれら治療手段を画像誘導ロボッ トや精密位置決めシステムと融合して標的治療 システムを実現するための技術であり，（5）は このような治療システム全体を統括制御し，信 頼性が高く高機能なシステム技術であり，安全 性が高く有効性の高いシステムに個々の要素技 術を集約するシステムエンジニアリングである。

海外においてもたとえば，米国 NIH National Cancer Institute $の 2006$ 年度の Strategic Investments in Advanced Technologies においてもイメージング と治療技術の融合による低侵襲治療の実現の重 要性が指摘されている.（http://plan2006.cancer. gov/technologies.shtml)

このように各種医用画像診断技術，生体計測 技術，ロボット等を使用した体内での精密位置 決め手術，標的部位への治療手段の運搬技術開 発を通じて，標的治療技術というものに発展す るものと期待される. 


\title{
整形外科におけるナビゲーション医療の現状
}

\author{
大阪大学大学院医学系研究科器官制御外科学
}

菅野 伸彦

近年，コンピュータ技術を駆使した種々の手 術支援システムが整形外科手術用に開発され， 臨床的にも使用されるようになった。 コンピュ 一夕支援整形外科手術（CAOS）には，ナビゲー ションや手術支援ロボットなどがある ${ }^{1)}$ 。これら の CAOS システムは，共通して患者の解剖学的 情報をもとにコンピュータ上で診断治療計画を 立案し, 術中骨格の位置を計測しながらこれら の情報を患者自身に重衫合わせて外科医にみせ ることで手術操作を誘導したり，一部の手術操 作を自動的に行ったりしている．解剖学情報源 としては, X 線 CT (Computerized Tomography) が最も多く使用されている（CT-based system）. CT-based systemとして最初に臨床導入されたの が手術支援ロボットであるROBODOCである。 患者の大腿骨とROBODOC を Rigid Frameで連 結し，CT画像で計画したとおりにロボットアー ム先端につけたドリルで大腿骨を掘削し，人工 関節設置骨母床を正確に整形するものである. 手術操作前にロボットアームの先端につけたプ ローブで大腿骨に埋植したマーカを探査してレ ジストレーションを行うシステムで，2000年に 日本でも臨床治験が行われた。症例の追跡調査 で，人工股関節ステムの設置精度の高さ ${ }^{2)}$, 従来 法よりも術中脂肪塞栓が少ないこと ${ }^{3)}$, 術後の大 腿骨の荷重分散がすぐれストレスシールドによ る大腿骨近位の骨萎縮が少ないことが示された が4)，いまだ薬事承認されていない。現在日本で は，埋植マーカを用いない表面レジストレーシ ヨン法を採用した新しいソフトウエアによる ROBODOC が，医師の個人輸入で臨床使用され ている。一方，CEマークを取得した ROBODOC
は1995 年以来ドイツで急速に臨床使用がひろが $り^{5)}$ ，約 14000 例の手術が行われたが，不適切な 使用による筋損傷の合併症が報告され ${ }^{6)}$ ，イラク 戦争への派兵で欧米が対立する最中, 2003 年に FDA 未承認の米国製欠陥手術ロボットがドイツ 人患者をモルモットにしていると Spiegel に報道 され，術後機能に不満のある患者の法廷闘争を 助長し 2004 年より使用は中断されている. 2006 年 6 月のドイツ連邦裁での判決で, 神経損傷な どの合併症はロボットの欠陷によるものではな く従来の人工股関節手術でも起こりえる合併症 のひとつとの判断が示された. ROBODOCの製 造者である米国 ISS 社は，2006 年 FDA の 510K 承認をとり，表面レジストレーション法を採用 した新しいソフトウェアによるROBODOCの PMA 承認のための臨床治験を再開した。 以上の ROBODOCの臨床使用から見えてきた課題は, 薬事承認, 外科医の先進機器使用訓練, EBM に なる前の新規技術の導入法，不満足な結果に対 する責任の所在などが挙げられる。

一方，1990 年代後半には，手術室で使用可能 な赤外線位置センサー開発により術前 CT データ

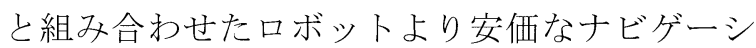
ヨンが開発され，脊椎手術において導入され， その後人工股関節手術や骨切り術にも使用され るようになった，春椎手術では，椎弓根スクリ ユーの正確な刺入 ${ }^{7)}$, 人工股関節においてはカッ プの正確な設置 ${ }^{8)}$ と良好な 5 年以上の成績が報 告されている9)。しかしながら, 正確な表面レジ ストレーションのためには外科医の知識と技術 を要し ${ }^{10)-12)}$ ，またソフトエアの性能でもレジス トレーションの精度が異なる。そこで，CTによ 
る 3 次元的な術前計画に要する時間やコストを 省き, 術中レジストレーションのステップを要 しないナビゲーションとして，移動式Cアーム 型 $\mathrm{X}$ 線透視装置（フルオロスコープ）を用いた Fluoro-navigation（または Virtual Fluoroscope）が 開発された。フルオロスコープは，骨折などの 手術治療に欠かせないものであるが，繰り返し $\mathrm{X}$ 線透視画像を撮像しなくてもいいように，1度 撮影した画像上で術具の位置を表示するナビゲ ーションである. 2 方向同時表示も可能で，手術 時間の短縮と低侵襲骨折固定法の精度向上に有 効である ${ }^{13)}$. C アームを定点中心に回転させな がら連続撮像してコーンビーム CT として 3 次元 画像を構築するシステムも開発されている ${ }^{14)}$. さらに，下肢のアライメントや人工関節の設置 位置および角度を計測評価するためには，画像 を用いなくても術中計測可能である。術中に解 剖学的特徵点を位置センサーでコンピュータに 入力して計測座標系を定義し，手術を誘導する ナビゲーション（Imageless system）もある。人 工膝関節全置換術で，下肢のアライメントの不 良を従来法よりも少なくすることが明らかで, 手術時間延長に見合う利点であるとされている 15)。これら，ナビゲーションシステムの共通の落 とし穴として，骨の位置計測をリアルタイムで 行うために骨に固定した Dynamic Reference Frameにゆるみを生じると，䛊った位置情報を提 供することになる．画像べースのナビゲーショ ンではこのゆるみは画像で確認できる機能をソ フトウエア上に盛り込めるが， Imageless ではこ れを確認することが困難である，以上のように ナビゲーションにおける課題は, 位置計測手術 機器として薬事承認のハードルは低いが，あく までもハードに対する承認であって，ソフトに ついての評価基準が明確でないこと，外科医の 先進機器使用訓練などが挙げられる.

最後に, ナビゲーション医療機器の社会経済 面での課題を挙げる。購入すれば使用ごとに保
険請求できて，投資を回収できる MRI や CT の ような診断装置と異なり，ナビゲーション医療 機器は，高度先進医療を除いて投資費用の回収 できる手段がない．開発メーカーからすると人 工関節用のソフトなら，人工関節の販売促進ツ ールとしての開発投資が行われるかもしれない が，インプラント費用の盛り込めない骨切り術 などのソフト開発は促進されない。また，開発 段階で臨床使用結果から改良を繰り返す必要や 臨床現場での適切な使用法のノウハウを獲得す るにあたり，開発企業が薬事承認前に参入でき る法的制度がない。

\section{参考文献}

1) Sugano N: Computer assisted orthopaedic surgery. J Orthop Sci 8; 442-448, 2003.

2) Nishihara S, Sugano N, et al.: Comparison between hand rasping and robotic milling for stem implantation in cementless total hip arthroplasty. J Arthroplasty. 2006; 21: 957-66.

3) Hagio K, Sugano N, et al.: Effectiveness of the ROBODOC system in preventing intraoperative pulmonary embolism. Acta Orthop Scand 74; 265-269, 2003.

4) Hananouchi T, Sugano N, et al.: Effect of Robotic milling on periprosthetic bone remodeling. J Orthop Res (in press).

5) Bargar WL, et al.: Primary and revision total hip replacement using the Robodoc system. Clin Orthop Relat Res; 354: 82-91, 1998.

6) Honl M, et al.: Comparison of robotic-assisted and manual implantation of a primary total hip replacement. A prospective study. J Bone Joint Surg Am.; 85-A: 1470-8, 2003.

7) Merloz P, et al.: Computer-assisted spine surgery. Comput Aided Surg. 3: 297-305, 1998.

8) Digioia AM 3rd, et al.: Comparison of a mechanical acetabular alignment guide with computer placement of the socket. J Arthroplasty 17: 359-64, 2002.

9) Sugano N, et al.: Mid-term results of cementless total hip arthroplasty using a ceramic-on-ceramic bearing with and without computer navigation. J Bone Joint Surg Br (in press). 
10) Sugano N, et al.: Accuracy evaluation of surfacebased registration methods in computer navigation system for hip surgery performed through a posterolateral approach. Computer Aided Surgery 6 : 195-203, 2001.

11) Nishihara S, Sugano N, et al.: Accuracy evaluation of a shape-based registration method for a computer navigation system for total knee arthroplasty. J Knee Surg 16;98-105, 2003.

12) Tamura Y, Sugano N, et al.: Surface-based registration accuracy of CT-based image-guided spine surgery. Eur Spine J 14: 291-297, 2005.

13) Kahler DM: Image guidance: fluoroscopic navigation. Clin Orthop Relat Res. 421: 70-6, 2004.

14) Holly LT, Foley KT: Percutaneous placement of posterior cervical screws using three-dimensional fluoroscopy. Spine 31: 536-40; 2006. 


\title{
耳鼻咽喉科領域におけるナビゲーション医療の現状と課題
}

\author{
金沢医科大学感覚機能病態学耳鼻咽喉科
}

友田幸一

耳鼻咽喉科・頭頝部外科領域は, 眼窩, 頭蓋 底などの危険部位が隣接し，また重要な神経， 血管が走行するなど解剖学的に複雑で個人差が 多く，そのため副損傷が後を絶たない. 1993 年 に欧米において初めてナビゲーションシステム が副鼻腔の手術に使用され，国内では 1995 年に 耳科と鼻科の手術に初㛐用され, 1997 年か ら本格的に導入が始まった. 現在国内の耳鼻咽 喉科医療施設の内，約 40 施設でナビゲーション システムが使用されている. 今日, その適応は 拡大され鼻副鼻腔手術以外に耳科・側頭骨手術, 頭頸部 - 頭蓋底手術, 顎 - 顔面外傷の他に生検, 手術教育，トレーニング，遠隔医療にまで広く 応用されてきている.

\section{1. ナビゲーション機器の現状}

2003 年に全国の主要病院耳鼻咽喉科(202 施設) にアンケート調查を行い, 回答の得られた 98 施 設の結果をまとめ概略を報告する。

ナビゲーションシステムを使用した施設は 29 施設で，使用された機種は光学式が圧倒的に多 く, 次に磁気式, アーム式の順であった。使用 頻度は, 年間 $1 \sim 10$ 症例が 14 施設, $11 \sim 49$ 症 例が 10 施設, 50 症例以上が 5 施設で, 開始年度, 適応疾患の選択によって施設に差があるように 思われた。レジストレーションに要した平均時 間は, 10 分以内が 5 施設, $10 \sim 20$ 分が 14 施設, 20 分以上が 6 施設で，最長は 60 分というのが 1 施設あった。これは使用頻度の差によるものと 考えられた.ナビゲーション使用中の機器のト ラブルについては, ワークステーションのフリ 一ズが 3 施設, 磁気式で手術器具による磁場へ
の影響が報告されている。

機器の優れた点と問題点については，優れた 点は各機種によってそれぞれ異なるが，総じて 光学式が取り扱いや精度の面で優れている傾向 であった。しかし反面レジストレーションに時 間がかかるという問題点も指摘されている。ま た最近の機器はレーザーによるレジストレーシ ヨン, 画像上での計測機能, タッチパネル式で 4 本のプローブまで使用可能など性能のアップが なされている. 一方, 問題点の多くは, レジス トレーションの時間と，誤差に集約できる。前 者はすでに述心゙たが，後者については，各施設 で大きく異なり $1 \mathrm{~mm}$ 以下の所から 4-5 mm の施 設まであり，大体 $2 \mathrm{~mm}$ 前後が約 20 施設ともつ とも多かった。特に耳科手術と頭蓋底手術にお いて深部で誤差が大きくなる傾向がみられてい る.

\section{2. ナビゲーション手術の現状}

アンケートの結果, 29 施設全体の手術件数は 1264 例で，領域別では鼻科手術が最も多く904 例 $(71.5 \%)$, 次に頭頸部・頭蓋底手術 181 例（14.3 $\%)$ ，耳科手術 179 例（14.2\%）の順であった。

まず基本的かつ共通する適応は以下の 3 つの 項目があげられる.1）再手術例：解剖学的ラン ドマークが欠如した例，拡大手術の術後など。2) 高度, 多発病変: 一解剖領域外一進展した例, 副鼻腔の多房性囊胞など. 3) 奇形手術：形態, 機能の保存のため. 特に絶対適応と考えられる 手術は，耳・側頭骨領域では先天性外耳道閉鎖症， 鼻副鼻腔領域では慢性副鼻腔炎 (再手術), 多胞 性囊胞，先天性後鼻孔閉鎖症，頭頸部領域では 
骨腫, 線維性骨異形成症, 鼻咽腔血管線維腫, 頭蓋底手術である。それから耳鼻咽喉科・頭䅡 部手術においてナビゲーション手術は必要かど うかについては, 91 施設中「必要」は 72 施設,「必 要ない」は 3 施設, 「どちらでもない」が 16 施 設であった。また国内外の 40 人の医師（全症例 数 814 例) の調査の結果, ナビゲーション手術 によって副損傷は全く無く, $80 \%$ 以上の医師が 安全性を認めている．ただシステムの設定のた めの手術時間の延長はあるが, 必要以上の手術 を避け，低侵襲で，取り残しの無い手術ができ ることから，術後創傷治癒ならびに入院期間の 短縮など医療経済効果も得られている.

\section{3. ナビゲーション手術の課題}

今後の課題として, 機器の精度の向上とレジ ストレーション方法の改善によってどこまで誤 差を少なくできるか, さらに手術に応じたプロ ーブの改良が望まれる. 頭頸部・頭蓋底手術では, 手術操作による部位の変化 (藏器シフト), 義歯 による画像のアーチファクト, 3 次元画像併用の 問題などがあげられる．また昨年, 慈恵医大で「画 像支援ナビゲーションによる内視鏡下鼻内副鼻 腔手術」が先進医療として承認され, 今後他施 設からも申請が予想されるため, ナビゲーショ ン手術の適応と評価を含めたガイドラインの作 成が必要と考えられる. 


\title{
脳神経外科におけるナビゲーション医療の実際
}

東京女子医科大学大学院 先端生命医科学研究所 先端工学外科

\author{
村垣善浩, 伊関 洋, 中村亮一, 高倉公朋
}

20 世紀, 外科学は様々な診断機器・手術器具 の開発によって大きな発展を遂げた．外科医は それらの優れた診断機器による術前情報を判断 し，新しい手術器具の習得に研鑽しより安全で 確実な手術を目指してきた．加えて 1990 年代後 半，技術革新により 21 世紀を担う新しい外科技 術が登場した。一つは循環器・腹部外科におい て外科医の新しい“手”となりうる da Vinciや Zeusなどの手術用 “ロボット”，もう一つは脳神 経外科において外科医の新しい“目”となりう る術中 MRI やナビゲーションである.

ナビゲーションは，手術操作の部位を CT や MRI 上で示すもので，日本人が最初に開発した 医療機器である.1991 年加藤ら（大阪大学）が 磁気方式で, 渡部ら（東京大学, 現自治医科大学） が機械式ア一ム方式で報告した。しかし赤外線 方式（Poralis, Northern Digital, Canada）が開発さ れて以来, 脳神経外科領域で世界的に普及した。 非常に有用であるが，一般のナビゲーションは 手術前に撮影した画像を元にしているため手術 中の臓器が移動した場合に一脳の場合は脳脊髄 液流出などにより $4-8 \mathrm{~mm}$ 程度沈み込むことが 多く Brain shift と呼ばれているーそれが誤差とな る.

我々は 2000 年にオープン MRI を核としたイン テリジェント手術室を構築し, 同時に術中の MRI を撮影した画像で行うナビゲーションを開 発した。これによりアップデートな最新情報を 的確に術者に伝え, 術者を残存病変部へと誘導 することが可能で，脳偏位の問題も解決できた (update navigation)。新規コイルや登録マーカー に開発により, 平均誤差 $0.9 \mathrm{~mm}$ を達成した。ま
た様々な機能追加を行い, 従来の 2 次元表示に 加えた 3 次元表示, 目標とする腫瘍部分のデジ タル抽出（分画化）によるわかりやすい表示と 術者に音で知らせる方式，また重要な神経線維 (たとえば運動神経）を撮影しナビゲーションで 連動する方式，が可能になっている.

2006 年 6 月までにインテリジェント手術室で 行った 400 例の手術を行い，291 例でナビゲーシ ヨンを行った。うち境界不鮮明な脳腫瘍である 神経膠腫 $(283$ 例) では特に有用で, 結果として 平均摘出率 $93 \%$ を得た。最も大事なことは 395 例 $(99 \%)$ で手術を完遂し，再手術必要な残存 病変がなく, 最終病理診断がついたことである. すなわち確実に目標病変に到達できるシステム といえる．また一般開頭術で $1-3 \%$ とさる術 後出血も $0.5 \%$ と少なかった. また予想外の合併 症は認めなかつた。

インテリジェント手術室での術中 MRI とナビ ゲーションの実際を提示するが，これら客観的 な“信頼できる”可視情報を術中に提供するシ ステムは, 治療効果向上とともに安全確保 (判 断に迷ったら少なくとも位置は確認できる）に おいても非常に有用である。 


\title{
内視鏡外科におけるナビゲーション医療の現状
}

\author{
大阪医科大学一般・消化器外科
}

奥田準二, 谷川允彦

1990 年に腹腔鏡下胆囊摘出術が本邦に導入さ れて以来, 内視鏡外科手術（腹腔鏡下手術）は 胃癌や大腸癌など種々の消化器疾患に低侵襲手 術として適用されるようになってきた。しかし， 腹腔鏡下手術では，触診が行えず，視野が狭く て全体像を捉えにくいために，主要血管の走行・ 分岐形態や病変と周囲臓器との関係など個々の 患者の外科解剖の把握が困難なことも稀でなく, これらの外科解剖を誤認して出血, 虚血や臟器 損傷を併発する危険性がある。これらの問題を 解決す心゙く，おれわれは3D-CT を活用して個及 の患者様の外科解剖を構築し, 特に胃癌と大腸 癌に対する腹腔鏡下手術の綿密な術前シミュレ ーションと術中ナビゲーションに活用してきた. その実際としては, 腹腔鏡の術野に合わせるよ うに Integrated 3D-CT 画像を対応させてリンパ節 郭清と血管処理の術中ナビゲーションを行って いる.さらに, Integrated 3D-CT 画像を病変部腸 管と他臓器との関係までも描出した画像（Virtual surgical anatomy : オーダーメードの外科解剖）に 発展させた。 なお, Volume GRID-webというソ フトを用いることでサーバであるワークステー ションに手術室のPCから LAN で接続でき，手 術室で瞬時に術野に合った画像を取り出すこと ができるようになった。すなわち, Integrated 3D-CT 画像はVirtual surgical anatomyに発展し, 個々の患者に合わせたオーダーメイドの外科解 剖を構築して腹腔鏡下手術をより安全・的確・ 迅速に支援できるようになってきている。これ らの画像支援によるシミュレーションやナビゲ 一ションは, 内視鏡外科の教育・トレーニング においても極めて有用であり, 画像処理ソフト
の開発, リアルタイムナビゲーションや術野へ のスーパーインポージングの応用と相まって広 く普及していくものと考えられる.さらに，今 後の診断能の向上を考えると，過大なリンパ節 郭清を避ける一助となり，腹腔鏡下手術と相ま って真の低侵襲オーダーメイド手術をナビゲー ションできると期待されている. 


\section{胎児外科におけるナビゲーション医療の現状}

国立成育医療センター特殊診療部 ${ }^{12}$, 国立成育医療センタ一第二専門診療部 2), 国立成育医療センタ一研究所移植・外科研究部 ${ }^{3)}$, 東京大学大学院情報理工学系研究科 ${ }^{4)}$, 東京大学大学院新領域創成科学研究科 ${ }^{5}$, 東京女子医科大学大学院先端生命医科学研究所 ${ }^{6}$, 早稲田大学理工学部機械工学科 ${ }^{7)}$, (独) 日本原子力研究開発機構 ${ }^{8)}$, アロ力株式会社 ${ }^{9}$, ペンタックス株式会社 ${ }^{10)}$

千葉敏雄 ${ }^{1)}$, 原田香奈子 ${ }^{1)}$, 藤崎正之 ${ }^{2)}$, 絵野沢伸 ${ }^{3)}$, 土肥健純 ${ }^{4)}$, 下山 勲 ${ }^{4)}$,

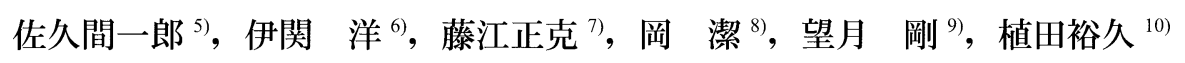

胎児の病態は, 時に分婏までの間, 不可逆的 に子宮内で進行・増悪するため, 従来の出生後 医療のみでは治療成績の向上に限界がある.胎 児（ないし胎盤）外科手術は，このようなハイ リスク児に子宮内で外科的処置を行うもので, 救命率の向上や患者長期予後の大幅な改善, 医 療費の低減を期して, 双胎間輸血症候群, 胎児 腫瘍, 中枢神経・心臟疾患等広範な疾患に対し 施行されてきた。そしてこの手術では, 子宮切 開を伴う胎児の直視下手術から，より低侵襲性 の手技（内視鏡下, 超音波ガイド下）への移行 が近年試みられている。しかし, 狭い子宮腔内 で行う胎児（羊水中に浮遊）や胎盤に対する手 術では, 術中画像や手術機器の機能的制約が有 効な治療を妨げていることも事実である。そこ で我々は, 本手術術中に効率的かつより安全な 操作を支援する “新しい目（画像技術）と手（手 術機器)” の開発に取り組んでおり, 今回は特に 前者の現況を中心に述べてみたい。

胎児手術の特異性から, 開発中のこれら新し い画像技術は，超音波診断装置を基本としたも のになるが，主なものとしては，鳥瞰図ナビゲ ーション（胎盤表面血管分布を把握する）, 近接 覚ナビゲーション（子宮内危険領域一の接近を 警告)，子宮内治療支援に特化された $3 \mathrm{D} / 4 \mathrm{D}$ 超音 波画像装置, 3D 内視鏡 (細径, 直視 / 斜視), マ イクロ MRI 等が挙げられる. 鳥瞰図ナビゲーシ
ヨンとは，超音波画像上の（狭視野）内視鏡画 像をつなぎ合わせることで擬似的に視野を拡大 する技術であり, 対象部位の全体像把握に役立 つ. 近接覚ナビゲーションは, 手術対象の危険 領域を術前画像にて設定し，その領域に対する 手術機器 - 内視鏡先端の術中接近度を常に監視 し，画面の色調変化や警告音にて接触を防ぐも のである.さらに 3D 内視鏡としては，先端に CCD を 2 つ配置した世界最小径（径 $5.4 \mathrm{~mm}$ ）の 硬性鏡開発に成功している. 最後に, マイク口 MRI は, MRI 信号受信コイルを細径内視鏡（MRI 対応）先端に取り付け, MRI 磁場内で, 内視鏡 による藏器表面観察とその梁部の形態学的観察 を同時に行ないうるものである.

一方, “新しい手”としては, 複合光ファイバ, 多自由度ロボット鉗子, 集束超音波装置(HIFU) などの手術機器開発を進めている。今後これら の各要素技術の完成度を一層高め, 同時にシス テムとしての統合を図る計画である。そしてこ のような試みは, 単に胎児手術という特異的領 域のみならず，小児・成人における広範な疾患 を対象とする手術成績全般の向上にも大いに資 するものと考えている. 


\title{
ナビゲーション医療分野の研究開発と普及に向けての法制度上の課題
}

\author{
慶應義塾大学大学院法務研究科 (法科大学院) - 医学部外科
}

古川 俊 治

\section{1. 医療機器を用いる臨床研究に対する薬事 法規制の問題}

2002 年の薬事法改正以前は, 将来製品化する 意思のない段階の開発途上の機器については, 医療機関が医療機器企業からその提供を受けて 医師・医療機関が主体となって行う治験外の臨 床研究に供されることが，少なからずあった。 このような臨床研究においては，用いられてい る機器自体が将来製造・販売されることはない し, 臨床研究の成績が承認申請などの行政目的 に利用されることもないから，薬事法の枠外と いうのが一般的な考え方であった。実際には， このような臨床研究は, 医療機器開発の早い段 階から医療側と企業側が協力し合い, 臨床上の 問題点を把握し，製品化へ向けた開発を的確な 方向へ進めることに大きく役立っていた. とこ ろが，2002年の薬事法改正を契機として，医療 機関が行う臨床研究に係る薬事法上の適用関係 の明確化が図られることになったため,このよ うな製品に至らない開発段階の機器であっても, 企業において作成されたものについては，医療 機関への提供が規制されることになった。

医薬品が医療機関における遺伝子を用いた研 究などから創造されるのと異なり, 医療機器の 場合，医師・医療機関が企業の関与なしに自ら 設計・作成することは著しく難しい. 一方で, 企業が，一切の臨床試用なしに，動物実験など だけで, 当初より治験を前提とした医療機器を 開発するというのは，ほとんど不可能である. このため，現実的な方法は，医師が外国企業か ら機器を個人輸入し，これを臨床研究で用いる ことが中心となってしまい, 我が国のロボット
研究に支障を来たす結果となっている.

薬事法は, 治験制度 (薬事法 2 条 15 項, 14 条 3 項, 80 条の 2) の存在によって明らかなように, 未承認品目の医薬品・医療機器が提供される場 合があることを当然に予定しているのであり， 治験以外の未承認品目の医薬品・医療機器等の 提供についても，一律に禁じる趣旨とは考えら れない。一方で, 薬事法の目的として，「医療上 特にその必要性が高い医薬品及び医療機器の研 究開発の促進のために必要な措置を講ずること により，保健衛生の向上を図ること」が掲げら れているのであり (1 条), 品質・有効性及び安 全性の確保のために必要な規制の下に，医療上 特にその必要性が高い医療機器の研究開発の促 進のために必要な未承認品目の医療機器の提供 を行うことは，可能と考えられる，特に，医療 機器開発が, 医薬品開発と異なり, 早期の企業 との連携が不可欠である点を十分に考慮し，医 薬品とは別個の, 医療機器開発研究に関する新 たなルールを創設することが必要であろう.

\section{2. 費用の問題}

現在，治験その他承認された一部を除く先進 医療には，保険医療における特定療養費制度の 適用は認められておらず，先進医療機器を用い た診療費用は，全額，患者の自費（または医療 機関の負担）となる.この点も, 新規医療機器 開発推進の大きな障壁となり, また, 患者にも 重い負担となっている. 今後は, より一層, 選 定医療制度を弾力的に運用し, 先進医療機器診 療に対し早期の保険医療給付の併用を認めるよ う要請していく必要があるであろう。 


\title{
ナビゲーション医療分野 ガイドライン学会案のポイント
}

\author{
精密手術用機器技術ガイドラインWG 座長
}

橋爪 誠

当 WG では 3 年以上にわたつて議論を行ない, その中で扱われた課題は多岐にわたる。現在の 案（作業案）のポイントは本抄録に収録の資料 でご覧いただくことができるので，ここでは主 な論点の議論のいきさつについて紹介する.

ガイドラインの方向性 : この分野には, JIS, ISO 等の標準規格はもとより FDA のガイダンス など参考になるものが存在しない。 また，拡大 を続けている分野であり，当学会でも様々なコ ンセプトが提唱されていることから，分野全体 を俯瞰する上位概念的なガイドラインをまず構 築し，その下に個別のシステムに関するガイド ラインを派生させることとした。 上位概念的な ガイドラインは抽象的で具体性に欠けるものと ならざるを得ないが，評価方法などの考え方を 示すことは一定の意義がある物と考えた．また， 個別のシステム向けのガイドラインも，数值的 なハードルが定義できる項目は例外的で，多く は検討すべき項目を列挙する等の記載になる. また，ガイドラインである以上，強制力は存在 しない.

定義：検討開始当初の最も大きな課題は，ナ ビゲーション，マニピュレータ，ロボットなど の手術支援のテクノロジーが多岐にわたり，そ の定義が簡単で無かったことである，将来の拡 張性も重要と考えた。これに対しては「精密手術」 とそのための「精密手術用機器」の定義を提案 して，将来的に新しい技術が登場してもなるべ く含まれるような枠組みを作った。
臨床研究：基礎研究と実用化の間の「死の谷」 を乗り越えるには臨床研究の振興が重要と考え た。新しい手術機器の開発では，試作機を用い た臨床を繰り返して改良していく方法が以前か らとられてきた。しかし平成 14 年の薬事法改正 で医師主導治験が導入され，企業から未承認機 器の提供を受けて前記のような改良のための臨 床研究を行うのは困難になった。 そこで承認申 請のための治験以外の臨床研究の道を開くこと, その一方で臨床研究の安全性を高めるためのコ ンバージョン条件を課すことをセットで議論し た。臨床研究の制度問題については広く認識さ れるに至ったこともあり，技術的なガイドライ ンとは別個に取り組むことになった。

臨床研究段階の機器の安全性：製品を理解す る医師が限定的に使う臨床研究では，製造品質 は製品と全く同じである必要はないと考える。 反面，研究だからと言って緩和できない事項も 存在する，研究開発から臨床研究の前までに取 るべきリスク対策や評価試験をガイドラインで 示すことができれば，研究開発上の時間やリソ 一スの無駄を省き, 臨床研究の安全性を向上さ せ，さらに倫理委員会の参考にもなるはずであ る.これらを集めて「研究開発のガイドライン」 としている. 内容的には今後一層の検討が必要 である。

機械システム安全 : 機械システムの安全設計 で重要な, 非常停止動作と復帰動作, 停電など の外的要因への耐性について議論した。産業用 ロボットに関する ISO 規格が発効しているほか, 
医療用に限らず人間共存ロボットシステムの安 全性に関しては確立した基準が存在しない，前 記の ISO 規格は産業用となっているので，直ち に医療環境での安全には適用できないが，そこ で例示されているハザードとその評価法は参考 になる。

またソフトウェアで制御される医療機器であ ることから，ソフトウェアの品質維持の仕組み が必要である. 医療機器のソフトウェア品質に 関しては米 FDA の要求がある。本ガイドライン にどのように反映するかは今後の精查が必要で ある。

医学的な有効性の評価方法 : 臨床試験によら ないと評価できない部分を除いて，なるべく非 臨床試験で評価可能とすること, 典型的な臨床 試験のエンドポイントを幾つか仮定して，その 評価プロトコルを例示することを目標として意 見交換を行った。

例えば，機械の固有誤差が危害に至らない程 度に小さければ医学的には無視できる誤差と言 えるはずである。しかし「無視できる誤差」の 大きさを決める事が容易でない，最終的には安 全率の設定にかかわることであり，臨床系学会 のコンセンサスが必要と思われる.

その他, 有効性の標榜に対する評価方法につ いても検討を開始している，基本的には個別の 装置ごと，個別の標榜項目ごとの試験法のデザ インが必要であり, 一般化は難しい。しかし多 くの精密手術用機器が標榜するであろう有効性 項目は種類も限られることから，その考え方を 示す事は可能である.

例えば，「使いやすさ」を示す目的の評価試験 では，被験者は患者ではなく医師である，実験 心理学的な落とし穴に注意しながら動物実験や ドライラボでの評価することで，治験によらな くても科学的な評価が可能である，といった点 を述べている.
コンバージョン：多くの議論がなされ，試案 として一定の完成度を持っている. 臨床試験段 階でコンバージョンを想定することは当然の事 と考え，これを要件としている，普及段階でも 要件とするかについては，検討していない．

ところで, 従来の方法では不可能な治療法を 実現する革新的な治療法の場合，コンバージョ ンは不可能かも知れない，コンバージョンを要 件とすることは革新を阻害することになる可能 性がある。例えば，その条件ではステントの臨 床試験は不可能のように思える。しかし安易に 臨床試験を実施して事故になれば，原因の如何 を問わず，その研究だけでなく分野全体に風評 被害をもたらし，分野を潰す事になりか称ない 以上, 臨床試験には万全の体制で望むべきと考 える.

トレーニング : トレーニングの方法論に関し てはほとんど手つかずの状態であるが，極めて 重要な課題と認識している. 